\title{
Gender-Based Organizational Citizenship Behavior Disposition for Public High School Teachers in Mataram, Lombok-Indonesia
}

\author{
Sudirman Wilian ${ }^{1,2}$, Lalu Muhaimi ${ }^{1,2}$, Syafruddin ${ }^{1,3}$, Joni Rokhmat ${ }^{1,4, *}$, Fika Ariani ${ }^{1}$, Harsanah $^{1}$ \\ ${ }^{1}$ Department of Educational Administration, Postgraduate Program \\ ${ }^{2}$ Department of English Language Education, Teacher Training and Education Faculty \\ ${ }^{3}$ Department of Sociology Education, Teacher Training and Education Faculty \\ ${ }^{4}$ Department of Physics Education, Teacher Training and Education Faculty \\ Universitas Mataram \\ Mataram, Indonesia \\ *joni.fkip@unram.ac.id
}

\begin{abstract}
OCB in the context of teachers is the behavior of doing good to other fellows in overcoming problems for the benefit of the school and preventing problems between them through building good relationships and respecting the rights and privacy of colleagues using such indicators as altruism, courtesy, sportPublic High Schoolship, conscientiousness, and civic virtue. This study aims to identify gender based-OCBdisposition and school location of the teachers of Public Senior High School No.1 in Mataram - Indonesia. It uses quantitative and qualitative approaches. Schools were divided into two, city center and suburban schools, from which two schools were randomly taken as samples (10 males and 10 female), yielding 86 teachers in all, 42 males and $\mathbf{4 4}$ females. While the quantitative data were taken using questionnaire and analyzed with the help of SPSS version 24 application, the qualitative data was generated from the analysis of the statement items in the questionnaire. The result shows that, on the statistical test at 0.05 significance level, only the third test that showed a sig value less than 0.05 (i.e. 0.044) while the other five tests revealed a sig-value greater than 0.05 . The conclusion was that there are differences in the OCB of Public Senior High School teachers located in the suburbs and that of the city center of Mataram (third-test), but there is no difference in $\mathrm{OCB}$ between male and female teachers at the center and at the suburbs. Meanwhile, there is no difference in OCB for male Public High School teachers in the suburb and that of women in the city center of Mataram. The same is true with male Public Senior High School teachers in the city center and women on the outskirts of Mataram. The OCB disposition of teachers from the highest to the lowest level is on the indicators of conscientiousness, civic virtue, altruism, courtesy, and sportPublic High Schoolship for teachers in downtown while in the suburbs, the third and fourth places change positions.
\end{abstract}

Keywords-Organizational Citizenship Behavior (OCB), gender, Public High School teacher, central and suburban schools

\section{INTRODUCTION}

The success of a school in achieving predetermined goals, on one hand, is highly dependent on the performance of all human resources in managing assets. On the other, the resources themselves are separated into two major groups, namely the principal as the leader, and the teaching and education staffs as subordinates. How do all these subordinates perform depend on the educational management process carried out by the school principal.

Educators with diverse educational and life backgrounds tend to show mixed responses to the workload at hand. Some tend to only want to complete the work they are obliged to do. This group tends not to care about other fellow educators who are busy with quite a lot of workloads even though they are also able to help complete other's work and are not working because they have finished doing their assignments. On the other hand, there are quite a lot of educators who volunteer to help their friends who have more workloads.

In managing an organization, the behavior of educators above is part of the discussion of organizational behavior which includes individual, group, and overall behavior in the organizational structure to achieve common goals, namely the goals of organizing the organization. This behavior is known as Organizational Citizenship Behavior (OCB).

There are at least five main dimensions of OCB, namely altruism, courtesy, sportPublic High Schoolship, conscientiousness, and civic virtue. All these dimensions discuss the opportunities for the behavior of educators as subordinates in a school. In general, this behavior describes the willingness to do work that is not formally his responsibility (adopted from the opinion of Organ [1]).

From the perspective of gender, male and female educators have several different characters. These differences include, 
among others, in terms of motivation, orientation, skills, and attitudes in carrying out their performance. In general, these differences are related to the mindset and basis of decision making for the aspects of motivation, results or relationships, and long or short term aspects of orientation, leadership, techniques, or relationships for aspects of skills, as well as assertiveness, objectivity, and flexibility for aspects of attitude (Adopted from Setiawan et al. [2]).

As consideration, the author's crude observations show that male and female educators tend to have different behaviors. Although these differences are not absolute, it is generally accepted that these observations can be justified. The difference is that female educators are more empathetic when they see co-workers who are experiencing problems or difficulties. Some of them volunteered to help complete the work which was not their responsibility. Of course, based on the five OCB indicators, these behavioral differences may appear in educators or teachers.

On the other hand, the author's rough observations also show that in the central and suburban schools there tend to be differences in the behavior of educators. Educators in suburban areas tend to have better togetherness than in urban centers. This may be due to differences in the performance demands of these schools. There is a tendency for schools in the city center to have higher quality graduate outcomes than those in the suburbs.

This author's rough observation needs to be continued with a more in-depth identification of the real situation of male and female educators in these schools. Next, we need to further examine the character of the OCB in terms of gender and school location.

\section{A. Formulation of the Problem}

Following the title and with the orientation of exploring how OCB male and female educators are viewed from their school locations, the following four problems are formulated: 1) Is there gender influence on the OCB of educators in Public High School in the city of Mataram ?; 2) Is there any effect of school location on the OCB of teaching staffs in Public High School in this city ?; 3) Is there any influence of the interaction between gender and school location on the OCB of teaching staffs in this city?; and 4) What is the disposition of OCB between male and female teaching staffs of Public High School in the central and suburban areas of Mataram City?.

\section{LITERATURE REVIEW}

\section{A. Definition of Education Management}

Organizational Citizenship Behavior (OCB) development is related to managerial activities. Managerial itself is a characteristic of noun management. This linkage underlies why the OCB discussion cannot be separated from the management discussion. Furthermore, based on this explanation, the discussion of management can refer to the discussion of management in which in the context of education the expression management of education or management of education appears. The word "management education" consists of two words "management" and "education". So, the acronym of the two words can be interpreted as a managing activity applied to educational activities. Therefore, to understand the meaning of educational management, the authors consider it is sufficient to discuss the notion of management.

Moekijat [3] defines the management of several figures, namely Atmosudirjo, Terry, Yoder, and Sarwoto, as well as from a dictionary of management terms. He interprets management from three aspects, namely people, processes, and power systems. The first aspect means that all people who have the main function or activity including work leaders. The second, management is related to downward-directed activities, namely in the form of work to achieve certain goals. Finally, the third states that management is related to a system of authority or authority so that people carry out work.

Terry and Rue [4] argued that management is a specific process, such as planning, organizing, mobilizing, and controlling to determine and achieve organizational goals. Next, Yoder as quoted by Terry and Rue [4] stated that management is a process of planning, directing, and monitoring. Sarwoto [5] stated that management is a process that utilizes the elements of 'man', 'money', 'material' and 'method' (4 M) to efficiently achieve certain goals. Lastly, by definition of a Dictionary the term management is a process and people. As a process, management is the effective use of resources to achieve goals, and as a person, management is a leading official who is responsible for the running of the company or organization.

Zakiyudin [6] cites the notion of management from three sources, namely James A.F. Stoner, Mary Parker Follet, and Luther Gulick. James A.F. Stoner stated that management is planning, organizing, directing, and monitoring the efforts of organizational members and the use of other organizational resources to achieve organizational goals. Mary Parker Follet states that management is the art of getting work done through other people. Here, a manager achieves organizational goals by persuading others to carry out various jobs. Finally, Luther Gulick stated that management is a field of science that systematically seeks to understand why and how humans work together to achieve goals and create a system of cooperation that is more beneficial to humanity. Another source, Terry and Rue [4] stated that management is a process or framework that involves guiding or directing a group of people towards organizational goals.

Based on the various definitions above and adjusted to the focus of this research, management or management has three perspectives, namely people, processes, and power systems. The people aspect shows that the principal has a function as a leader in educational performance. The process aspect shows that management means activities that are downward-directed, namely in the form of work to achieve educational goals Finally, the aspect of the power system implies that there is authority or authority of the leadership of the education unit 
towards their subordinates. Concerning OCB, as a leader, the principal plays a role in developing OCB for his subordinates, such as teachers.

\section{B. The Conceptual Definition of Education Management is Related to $O C B$}

In the context of managing education in schools, there is a leader, namely the principal who has the authority to make policies to regulate or manage various activities in the field of education that must be carried out by his subordinates, namely teaching staff (teachers) and education staff (administrative staff to messengers) as well as managing all the supporting assets for the provision of education in a particular educational unit or school. Informally, school leaders have a moral responsibility in developing the OCB of their subordinates, including teachers.

\section{Organizational Citizenship Behavior (OCB)}

Organizational behavior includes three aspects, namely the behavior of individuals, groups, and overall behavior in the organizational structure. All of these activities are oriented towards gaining knowledge about behavior and are aimed at improving organizational effectiveness [7]. This organizational behavior can be both positive and negative.

One of the positive behaviors of subordinates is OCB. OCB has a meaning as individual behavior that is free and voluntary, not related to the reward system, and as a whole can increase the efficiency and effectiveness of the organization (Organ [8] also quoted by Ariyani and Zulkarnain [9]). Furthermore, Sarwono and Soeroso [5] stated that OCB is an act of someone outside of their obligations and does not pay attention to their interests. OCB is not based on a job description and a formal reward system but has a voluntary nature to cooperate with colleagues and is willing to take orders without complaint.

Williams and Anderson as quoted by Ariyani and Zulkarnain [9] states that contextual performance is related to character and therefore OCB cannot be separated from the demographic aspects of employees in the workplace. This study is in line with Podsakoff et al. [10] who stated that the cultural context influences OCB a lot. In its operations, OCB can be separated from the demographic factors of employees in the workplace. These demographic factors include gender, age, marital status, and employment status.

Smith, Organ, and Near [11] stated that OCB includes at least two separate dimensions, namely altruism (belief or practice of selfless and unconditional concern for the welfare of others) and generalized compliance (general compliance). Job satisfaction, which is a measure of mood, represents a direct predictive pathway to altruism but not to generalized compliance.

Organ [1] states that OCB is individual behavior that is not directly or explicitly recognized by the formal reward system. However, in 1997, he redefined OCB as a form of performance that supports the social or psychological environment on a given task or obligation.
He also states that there are five main dimensions of OCB, namely altruism, courtesy, sportPublic High Schoolship, conscientiousness, and civic virtue. Altruism is the behavior of helping other employees without coercion. For example, replacing coworkers who are absent or taking breaks, helping others who have more work, or volunteering to do something. The second dimension, courtesy, is to do good to others in overcoming problems related to the organization and to help prevent problems with colleagues, such as maintaining good relations with colleagues and respecting their rights and privacy.

The dimension of sportPublic High Schoolship is tolerance for situations that are less than ideal or uncomfortable at work. An example of a subordinate with a willingness to tolerate without complaining, refrain from complaining and cursing, not exaggerating problems, and not finding fault with the organization. The dimension of conscientiousness is a performance that exceeds the minimum. Samples arrive early so that they are more ready for work or on time each day. Finally, the civic virtue dimension is voluntary participation and support for organizational functions professionally and socially. Examples of being involved, caring, and taking responsibility for the continuity of the organization.

Referring to the six paragraphs of exposure to OCB and adjusted to the focus of this study, organizational citizenship behavior $(\mathrm{OCB})$ is interpreted as having indicators of altruism, courtesy, sportPublic High Schoolship, conscientiousness, and civic virtue. An indicator of altruism is the behavior of educators (teachers) to voluntarily help each other's work. The second indicator, courtesy, is the behavior of doing good to fellow teachers in overcoming problems for the benefit of the school and preventing problems between teachers by establishing good relationships and respecting the rights and privacy of colleagues.

The third indicator, sportPublic High Schoolship is an attitude of tolerance towards situations that are less expected in the work environment. Some examples are not complaining, not cursing, not raising problems, and not finding fault with the school for the situation. Fourth, conscientiousness includes such a behavior as arriving early, ready to work, and being punctual. Finally, civic virtue indicators consist of such things as voluntary participation and supporting for schools professionally and socially. Examples of involvement are caring and having a sense of responsibility for school continuity.

\section{Differences in the Character of Male and Female Educators}

Fajriati [12] who is also quoted by Setiawati et al. [2] stated that based on motivational indicators, male employees tend to have a more focused mindset and based on logic while female employees have a more focused mindset extends and bases on the aspects of feeling. These two mindsets create problems in making decisions during meetings and problems of work professionalism. The solution to the first problem is that there 
is a need for superior leadership intervention, while for the second problem a briefing is needed before the meeting begins.

Based on the orientation indicators, male and female employees can be differentiated as follows: Male employees are more focused on results, general in nature, and on a longterm orientation, while female employees are more focused on relationships, detailed in nature, and on short-term orientation. Problems that may arise from these two orientation groups are a lack of professionalism, a lack of meticulousness with small matters, and a lack of innovation. For these three possible problems, each solution is offered. It requires training in employee management training, needs a system or format of activities, and more often participates in training or seminars [2].

Based on the skills indicators, male and female employees can be differentiated as follows: Male employees have advantages in terms of leadership, techniques, and strategy while female employees have advantages in terms of administration and relations. This difference causes suboptimal performance problems when there is a displacement. The solution offered for this problem is that the manager must be selective in placing the work field. Furthermore, based on the attitude aspect, male employees tend to be assertive, objective, and flexible, while female employees tend to rely on feelings and are subjective. The problem that arises from this difference is that it is unprofessional and the solution is the need to live up to the values and culture of the organization (ibid).

\section{E. Differences in the Character of Teachers in Central and Suburban Schools}

Educators or teachers at schools located in the city center are generally more individual than teachers in the suburbs who have a more sense of kinship among teachers. Factors of this phenomenon include workload. In general, the workload is directly related to the quality of achievement of these school graduates. Schools in city centers tend to rank much higher quality graduate outcomes than schools in the suburbs. The quality of achievement of these graduates directly demands a better quantity of performance in both quantity and quality. This situation fosters a tendency to only pay attention to each other's work.

The results of the preliminary study indicate that in running a school organization, the authors find that whether they realize it or not, the leadership always tries to implement OCB-based management. They also wanted that OCB would develop in both male and female teachers without exception, as well as in both central and suburban schools of Mataram. The leadership expects that each teacher will position himself as a partner for every other individual teacher. With this type of management pattern, it is hoped that there will be harmonization of cooperation between fellow teachers as well as cooperation vertically, with the leadership and/or with educational staff, such as administrative staff, cleaning, security, and so on. If this situation can be realized, the OCB-based management pattern will become a very effective organizational management strategy.

OCB-based education management is needed in running an organization so that organizational goals can be achieved. In the preliminary study, indicators of an OCB-based education management strategy appear. Thus, research to explore the influence of gender, school location, both individually and collectively on the OCB of teaching staff, as well as mapping the OCB disposition of male and female teachers, in central and suburban schools is very likely to be implemented in public senior high schools in this city of Mataram, Indonesia.

\section{RESEARCH METHODS}

This study uses a mixed-method as a modification of the Explanatory Design [13]. In this method, quantitative data is used as a support for qualitative data and then the data is interpreted as a result of quantitative and qualitative analysis.

In this method, this research is carried out in two stages. Stage-1 is a qualitative stage with an implicit quantitative phase. This stage consists of preliminary study activities, analysis of questionnaire data-based management strategies, process observations, and qualitative data analysis. Furthermore, Phase- 2 is the interpretation phase of the Phase-1 process result data.

The research was conducted at Public High School in Mataram City. OCB quantitative data were taken using a questionnaire. Qualitative data regarding OCB-based education management were collected through process observation and interviews. Quantitative data were analyzed using the SPSS version-24 application, while qualitative data were analyzed based on the validation process of triangulation, reduction, and decision making of qualitative results. Furthermore, the interpretation of qualitative results is carried out supported by the results of quantitative data analysis.

\section{RESULTS AND DISCUSSION}

\section{A. Research Data}

Organizational Citizenship Behavior (OCB) data comes from 86 respondents consisting of 40 high school teachers in the suburbs of Mataram and 46 high school teachers downtown Mataram. Teachers of Public High Schools on the outskirts of Mataram were represented by 19 teachers $(8$ males and 11 females) provided by Public High School No.8 Mataram and 21 teachers from Public High School No. 6 Mataram (11 males and 10 females). Meanwhile, the teachers in the city center were represented by 23 teachers (11 males and 12 females) from Public High School No. 2 Mataram and 23 teachers from Public High School No.3 Mataram (12 males and 11 females).

The questionnaire instrument consisted of 27 statements spread into five OCB indicators, namely altruism indicator (6 statements), courtesy (6 statements), sport Public High Schoolship (6 statements), conscientiousness (4 statements), and civic virtue (5 statements). OCB scores for teachers at 
Public High School in the city of Mataram, both located in the city center and on the outskirts, specifically for male and female teachers at the two Public High School locations are shown in Table 1 to Table 2. The OCB score is the result of the quantization of the respondent's attitude towards each statement about OCB. The scores of 4, 3, 2, and 1 respectively indicate that they strongly agree, agree, disagree, and strongly disagree. In the table, each indicator has a symbol ind-1 to ind5 , respectively for indicators of altruism, courtesy, sportPublic High Schoolship, conscientiousness, and civic virtue. Furthermore, Table 5 to Table 11 shows the results of the OCB difference test at the Mataram City Senior High School using the SPSS version 24 application.

Table 1 shows the average OCB scores of Public High School teachers downtown Mataram is categorized for all teachers, male teachers, and female teachers. Except for indicator-3 (sport Public High Schoolship), it has a score of 2.98, for male teachers, all indicators have an average score of more than 3.00. This shows that the average respondent gave an attitude between agreeing to strongly agree with each OCB statement, while all-female teachers on average gave an attitude between disagreeing to agreeing with each OCB statement related to sport Public High Schoolship indicators. By approaching the OCB score to a value of 4 or 3 , there are only two groups of scores that are closer to value 4 (on the conscientiousness indicator for the group of all teachers and the group of male teachers) while the others are closer to score 3. This shows that the OCB statement regarding the conscientiousness indicator in the two groups of teachers on average gave a very agreeable attitude, meanwhile, the others on average agreed.

Table 2 shows the average OCB scores of Public High School teachers in the suburbs of Mataram, which were categorized for groups of all-teachers, male-teachers, and female-teacher. In contrast to Table 1 , except for indicator 1 (altruism), the female teacher group had an average score of less than 3.00, for all indicators and in all other groups of teachers had an average score of more than 3.00. However, all are closer to the value of 3.00 including those excluded above. So in general, PUBLIC HIGH SCHOOL teachers on the edge of the Mataram City have an agreeable attitude towards every OCB statement in all its indicators.

TABle I. The Average Score of OCB Teachers at Mataram City CENTRAL High SCHOOL

\begin{tabular}{|l|c|l|l|l|l|}
\hline \multicolumn{7}{|c|}{ The Average Score of OCB } \\
\hline & Ind-1 & Ind-2 & Ind-3 & Ind-4 & Ind-5 \\
\hline All teachers & 3.28 & 3.14 & 3.00 & 3.57 & 3.49 \\
\hline Male Teachers & 3.34 & 3.06 & 2.98 & 3.64 & 3.52 \\
\hline Female Teachers & 3.22 & 3.22 & 3.03 & 3.49 & 3.47 \\
\hline
\end{tabular}

TABLE II. OCB AVERAGE SCORE OF PUBLIC High SCHOOL TEACHERS IN THE SUBURBS OF MATARAM CITY

\begin{tabular}{|l|l|l|l|l|l|}
\hline \multicolumn{7}{|c|}{ The Average Score of OCB } \\
\hline & \multicolumn{1}{|c|}{ Ind-1 } & Ind-2 & Ind-3 & Ind-4 & Ind-5 \\
\hline All teachers & 3.08 & 3.16 & 3.03 & 3.43 & 3.30 \\
\hline Male Teachers & 3.18 & 3.20 & 3.04 & 3.35 & 3.39 \\
\hline Female Teachers & 2.99 & 3.12 & 3.01 & 3.51 & 3.21 \\
\hline
\end{tabular}

TABLE III THE AVERAGE SCORE RANK OF OCB TEACHERS OF CENTRAL High SCHOOL MATARAM CITY

\begin{tabular}{|l|l|l|l|l|l|}
\hline \multicolumn{7}{|c|}{ The OCB Average Score Rating / Rank } \\
\hline & Ind-1 & Ind-2 & Ind-3 & Ind-4 & Ind-5 \\
\hline All teachers & 3 & 4 & 5 & 1 & 2 \\
\hline Male Teachers & 3 & 4 & 5 & 1 & 2 \\
\hline Female Teachers & 3.5 & 3.5 & 5 & 1 & 2 \\
\hline
\end{tabular}

TABLE IV. OCB Average SCORE RATING FOR Public High SCHOOL TEACHERS IN THE SUBURBS OF MATARAM

\begin{tabular}{|l|l|l|l|l|l|}
\hline \multicolumn{7}{|c|}{ The Average Score of OCB / Rank } \\
\hline & Ind-1 & Ind-2 & Ind-3 & Ind-4 & Ind-5 \\
\hline All teachers & 4 & 3 & 5 & 1 & 2 \\
\hline Male Teachers & 4 & 3 & 5 & 2 & 1 \\
\hline Female Teachers & 5 & 3 & 4 & 1 & 2 \\
\hline
\end{tabular}

Table 3 shows the average OCB score rank for each indicator in each teacher group at the central of Mataram City. In general, indicator 4 (conscientiousness) has the highest rating followed by indicator 5 (civil virtue). Meanwhile, indicator 3 (sportPublic High Schoolship) has the lowest average OCB score. In the group of all teachers and group of male teachers, indicator 1 (altruism) has an average score rank of 3 while indicator 2 (courtesy) has an average score rank of 4 , meanwhile, in the female teacher group, these two indicators have the same score, namely 3.22 so that both of them have the same rank, which is 3.5 .

Table 4 shows the average OCB score rank for each indicator in each teacher group on the suburbs of Mataram City. In the whole group of all teachers and group of female teachers, the average scores in the order of rank 1,2, and 3 are the same, namely on the OCB indicators number 4,5 , and 2 or on indicators of conscientiousness, civic virtue, and of courtesy. Furthermore, rank 4 and 5 are respectively on indicator 1 (altruism) and indicator 3 (sportPublic High Schoolship) for groups of all teachers, as well as on indicator 3 (sportPublic High Schoolship) and indicator 1 (altruism) for female teacher group. Especially for the male teacher group, the average score with ratings 1 to 5 , respectively occurs in indicator 5 (civic virtue), indicator 4 (conscientiousness), indicator 2 (courtesy), indicator 1 (altruism), and indicator 3 (sportPublic High Schoolship).

Table 5 to Table 11 shows the results of the Mann-Whitney non-parametric statistical test with a significance of 0.05 to test whether there is a difference in the mean OCB score, respectively, between 1) male and female Public High School teachers on the edge of the city Mataram, 2) male and female Public High School teachers in the center of Mataram City, 3) teachers at the peripheral and central Public High School of Mataram City, 4) male and female Public High School teachers in Mataram City, 5) female Public High School teachers on the suburbs of Mataram City and male teachers in central of Mataram City, 6) female Public High School teachers in the center of Mataram City and male teacher in the periphery of Mataram City. Among the results of these statistical tests, only the third test (Table 7) shows the sig-value less than 0.05 , that is 0.044 , so that only in this test that accepts the alternative 
hypothesis $(\mathrm{Ha})$ and rejects the null hypothesis $\left(\mathrm{H}_{0}\right)$. The five other statistical test results, the first, second, fourth, fifth, and sixth tests respectively show the sig-value more than 0.05 , namely $1,000,0.741,0.697,0.087$, and 0.282 .

TABLE V. RESUlTS OF TEST ON DifFERENCES IN OCB FOR MALE AND FEMALE TEACHERS IN THE SUBURBS OF MATARAM

Ranks

\begin{tabular}{|c|l|l|l|l|}
\hline \multirow{2}{*}{$\begin{array}{c}\text { The Score of } \\
\text { OCB }\end{array}$} & Gender & N & Mean Rank & Sum of Ranks \\
\cline { 2 - 5 } & Female & 21 & 20.50 & 430.50 \\
\cline { 2 - 5 } & Male & 19 & 20.50 & 389.50 \\
\cline { 2 - 5 } & Total & 40 & & \\
\hline
\end{tabular}

Test Statistics $^{\text {a }}$

\begin{tabular}{|l|l|}
\hline & The Score of OCB \\
\hline Mann-Whitney U & 199.500 \\
\hline Wilcoxon W & 389.500 \\
\hline Z & .000 \\
\hline Asymp. Sig. (2-tailed) & 1.000 \\
\hline \multicolumn{2}{|c|}{ a. Grouping Variable: Gender }
\end{tabular}

TABLE VI. RESUlTS OF TEST ON DifFERENCES BETWEEN MALE AND FEMALE OCB TEACHERS IN CITY CENTER

\begin{tabular}{|c|l|c|l|c|}
\multicolumn{5}{|c|}{ Ranks } \\
\hline \multirow{3}{*}{$\begin{array}{c}\text { The Score of } \\
\text { OCB }\end{array}$} & Gender & $\mathbf{N}$ & Mean Rank & Sum of Ranks \\
\cline { 2 - 6 } & Female & 23 & 22.85 & 525.50 \\
\cline { 2 - 5 } & Male & 23 & 24.15 & 555.50 \\
\cline { 2 - 5 } & Total & 46 & & \\
\hline
\end{tabular}

\begin{tabular}{|l|l|}
\hline & The Score of OCB \\
\hline Mann-Whitney U & 249.500 \\
\hline Wilcoxon W & 525.500 \\
\hline Z & -.330 \\
\hline Asymp. Sig. (2-tailed) & .741 \\
\hline \multicolumn{2}{|c|}{ a. Grouping Variable: Gender }
\end{tabular}

TABLE VII. RESULTS OF THE MANN-WHITNEY TEST ON OCB DIFFERENCES FOR SUBURBAN AND CITY CENTER TEACHERS

\begin{tabular}{|c|c|c|c|c|}
\hline \multicolumn{5}{|c|}{ Ranks } \\
\hline & School Location & $N$ & $\begin{array}{l}\text { Mean } \\
\text { Rank }\end{array}$ & $\begin{array}{c}\text { Sum of } \\
\text { Ranks }\end{array}$ \\
\hline \multirow[t]{3}{*}{$\begin{array}{c}\text { The Score of } \\
\text { OCB }\end{array}$} & $\begin{array}{l}\text { Mataram City } \\
\text { Center }\end{array}$ & 46 & 48.54 & 2233.00 \\
\hline & $\begin{array}{l}\text { The Suburban of } \\
\text { Mataram City }\end{array}$ & 40 & 37.70 & 1508.00 \\
\hline & Total & 86 & & \\
\hline
\end{tabular}

Test Statistics

\begin{tabular}{|l|l|}
\hline & The Score of OCB \\
\hline Mann-Whitney U & 688.000 \\
\hline Wilcoxon W & 1508.000 \\
\hline Z & -2.013 \\
\hline Asymp. Sig. (2-tailed) & .044 \\
\hline
\end{tabular}

a. Grouping Variable: School location
TABLE VIII. RESULTS OF THE MANN-WHITNEY TEST ON DIFFERENCES BETWEEN MALE AND FEMALE OCB TEACHERS IN MATARAM CiTY

Ranks

\begin{tabular}{|l|l|l|l|l|}
\hline & Gender & $\mathbf{N}$ & Mean Rank & Sum of Ranks \\
\hline \multirow{3}{*}{$\begin{array}{c}\text { The Score of } \\
\text { OCB }\end{array}$} & Female & 42 & 44.57 & 1872.00 \\
\cline { 2 - 5 } & Male & 44 & 42.48 & 1869.00 \\
\cline { 2 - 5 } & Total & 86 & & \\
\hline
\end{tabular}

Test Statistics ${ }^{\mathrm{a}}$

\begin{tabular}{|l|l|}
\hline & The Score of OCB \\
\hline Mann-Whitney U & 879.000 \\
\hline Wilcoxon W & 1869.000 \\
\hline Z & -.390 \\
\hline Asymp. Sig. (2-tailed) & .697 \\
\hline & a. Grouping Variable: Gender
\end{tabular}

TABLE IX. RESUlTS OF THE MANN-WHITNEY TEST ON OCB DIFFERENCES OF FEMALE TEACHERS IN THE SubuRbS AND Male TEACHERS IN THE CITY CENTER

\section{Ranks}

\begin{tabular}{|l|l|l|l|l|}
\hline & $\begin{array}{l}\text { Gender \& School } \\
\text { location }\end{array}$ & N & $\begin{array}{c}\text { Mean } \\
\text { Rank }\end{array}$ & $\begin{array}{c}\text { Sum of } \\
\text { Ranks }\end{array}$ \\
\hline $\begin{array}{l}\text { The Score of } \\
\text { OCB }\end{array}$ & $\begin{array}{l}\text { Female teachers in } \\
\text { the Suburbs }\end{array}$ & 21 & 19.05 & 400.00 \\
\cline { 2 - 5 } & $\begin{array}{l}\text { Male teacher in the } \\
\text { city center }\end{array}$ & 23 & 25.65 & 590.00 \\
\cline { 2 - 5 } & Total & 44 & & \\
\hline
\end{tabular}

Test Statistics

\begin{tabular}{|l|l|}
\hline & \multicolumn{1}{|c|}{ The Score of OCB } \\
\hline Mann-Whitney U & 169.000 \\
\hline Wilcoxon W & 400.000 \\
\hline Z & -1.710 \\
\hline Asymp. Sig. (2-tailed) & .087 \\
\hline
\end{tabular}

a. Grouping Variable: Gender \& School location

TABLE X. RESUlTS OF THE MANN-WhitNEY TEST ON OCB DifFERENCES OF FEMALE TEACHERS IN THE City CENTER AND MALE TEACHERS IN THE SUBURBS

\section{Ranks}

\begin{tabular}{|c|c|c|c|c|}
\hline & $\begin{array}{c}\text { Gender \& School } \\
\text { location }\end{array}$ & $\mathbf{N}$ & $\begin{array}{l}\text { Mean } \\
\text { Rank }\end{array}$ & $\begin{array}{l}\text { Sum of } \\
\text { Ranks }\end{array}$ \\
\hline \multirow[t]{3}{*}{$\begin{array}{c}\text { The Score of } \\
\text { OCB }\end{array}$} & $\begin{array}{l}\text { Female teacher in the } \\
\text { city center }\end{array}$ & 23 & 23.35 & 537.00 \\
\hline & $\begin{array}{l}\text { Male teachers in the } \\
\text { Suburbs }\end{array}$ & 19 & 19.26 & 366.00 \\
\hline & Total & 42 & & \\
\hline
\end{tabular}

Test Statistics ${ }^{\text {a }}$

\begin{tabular}{|l|l|}
\hline & \multicolumn{1}{|c|}{ The Score of OCB } \\
\hline Mann-Whitney U & 176.000 \\
\hline Wilcoxon W & 366.000 \\
\hline Z & -1.077 \\
\hline Asymp. Sig. (2-tailed) & .282 \\
\hline
\end{tabular}

a. Grouping Variable: Gender \& School location

TABLE XI. OCB AVERAGE SCORE OF PUblic High SCHOOl TEACHERS IN MATARAM CITY

\begin{tabular}{|l|l|}
\hline & \multicolumn{1}{|c|}{$\begin{array}{c}\text { OCB } \\
\text { average } \\
\text { score }\end{array}$} \\
\hline $\begin{array}{l}\text { Teacher at Public High School on the Center of } \\
\text { Mataram City }\end{array}$ & 3.16 \\
\hline $\begin{array}{l}\text { Teacher at Public High School on the Suburbs of the } \\
\text { Mataram city }\end{array}$ & 3.08 \\
\hline
\end{tabular}




\section{B. Discussion}

In general, Public High School teachers in Mataram City have good Organizational Citizenship Behavior (OCB). This fact is shown, among others, in the acquisition of the OCB score, which is generally close to the value of 3.00, which qualitatively agrees with the descriptor of each indicator. Based on the average score ranking, OCB behavior quantitatively from the highest to the lowest is the conscientiousness indicator, civic virtue, altruism, courtesy, and the lowest is the sportPublic High Schoolship indicator.

Based on the order of the OCB average score as described in the paragraph above, the OCB disposition of PUBLIC HIGH SCHOOL teachers in Mataram, in order, from the most frequently carried out is: 1) performing above the minimum, 2) participating voluntarily in supporting school performance both professionally and social, 3) helping other teachers without coercion, 4) being kind to other teachers in overcoming problems related to school and helping prevent problems with other teachers, and 5) accepting and tolerating when school conditions do not match expectations so as not to complain, cursing, or find fault with the school.

In general, the gender of Public High School teachers in Mataram did not affect their OCB behavior. Likewise, the cross-variable gender and school location (edge and center of Mataram City) did not affect the OCB behavior of Public High School teachers. This shows that although female and male teachers have different characters [2,12] in implementing behaviors related to OCB are the same. Based on the authors' observations, currently, the roles of male and female teachers in developing education in schools are almost indistinguishable. Many female teachers are believed to be in pending positions in running school organizations.

However, the OCB behavior of Public High School teachers was influenced by the location of the school. Teachers at the central of Mataram City tended to have better OCB behavior than teachers in the suburbs of Mataram City. If it is related to the researchers' observations, in the sample schools, Public High School 2 and Public High School 3 Mataram were led by a school principal who in the author's view was classified as young. These school principals have a very high motivation to develop the school. One indicator is committing to work more than the minimum duration. This is following the fourth OCB indicator, namely conscientiousness. The OCB behavior of this school is in line with the OCB behavior of the teachers, namely this indicator generally has the highest average score.

Another cause of the above phenomenon is that the character of students in the city center and the suburbs is different. There is a tendency for students in the city center to come from schools at the junior secondary level which is much better in quality than those from rural areas. In addition, students in the city center also generally have a better life pattern than students in the suburbs. The families of Public High School students in the city center, some of whom have a high vision for the future in an effort to continue their education at the college level.

\section{CONCLUSION AND RECOMMENDATION}

\section{A. Conclusion}

From the results of data analysis, researchers can conclude that: 1) there is no influence of gender on the behavior of the Organizational Citizenship Behavior (OCB) of PUBLIC HIGH SCHOOL teachers in the peripheral and central of Mataram, 2) there is an effect of school location on the OCB behavior of PUBLIC HIGH SCHOOL teachers in Mataram City, 3) there is no influence of the interaction between gender and school location on OCB behavior of Public High School teachers in Mataram City. Furthermore, the disposition of the OCB behavior of teachers in the center of Mataram City, from the highest to the lowest score, consecutively on the indicators of conscientiousness, civic virtue, altruism, courtesy, and sportPublic High Schoolship while in the suburbs of Mataram City, from the highest score to the lowest, respectively on the indicator conscientiousness, civic virtue, courtesy, altruism, and sportPublic High Schoolship.

\section{B. Recommendation}

Principals still need to improve the OCB behavior of Public High School teachers, especially about sportPublic High Schoolship indicators. In particular, teachers need to be aware of being able to accept the condition of the school if the situation is or not by expectations, both from the aspects of infrastructure, academic environment, and social affairs. The head needs to urge teachers not to complain easily, to refrain from swearing, and not to exaggerate the problems the school is facing. Regarding further research, it is necessary to conduct an in-depth study of the strategies of the principals of Public High School in the center of Mataram City in developing OCB for their teachers.

\section{ACKNOWLEDGMENT}

We acknowledge the leadership of Mataram University and its staff, the leadership of Mataram University postgraduate and its staff, as well as Mataram University research institute who jointly approved and financed our research through the 2020 PNBP funds. We also acknowledge the leadership and teachers at Public High School 2, Public High School 3, Public High School 6, and Public High School 8 of Mataram which had allowed us to do a research in these schools. Finally, we would also like to thank our family and friends who have supported the implementation of this research.

\section{REFERENCES}

[1] D.W. Organ, Organizational Citizenship Behavior, The good soldier syndrome. Lexington, MA: Lexington Books, 1988.

[2] H. Setiawati, M. Anindityo, M.D.Z. Purba, N.Y. Niam, N.D. Wanodyanti, and A.S. Hakimi, Gender Difference Issues in Human Resource Management (Isu Perbedaan Jenis Kelamin dalam Manajemen Sumber Daya Manusia). Program Pascasarjana Sekolah Bisnis Institut 
Pertanian Bogor, 2015. [Online] melalui URL: https://www.academia.edu/21487356/ISU_PERBEDAAN_JENIS_KEL AMIN DALAM MANAJEMEN SUMBER DAYA MANUSIA [Diakses 22 Pebruari 2020].

[3] Moekijat, Introduction to Management Information Systems (Pengantar Sisitem Informasi Manajemen), cetakan ke-9. Bandung: Mandar Maju, 2005.

[4] G.R. Terry dan L.W. Rue, alih bahasa G.A. Ticoalu, Fundamentals of management (Dasar-dasar Manajemen), cetakan ke-13. Jakarta: PT Bumi Aksara, 2013.

[5] S.S. Sarwono and A. Soeroso, "Demographic Determination of Organizational Charitative Behavior (Determinasi Demografi terhadap Perilaku Karitatif Keorganisasian),” Jurnal Siasat Bisnis, vol. 6, no. (1), 2001.

[6] A. Zakiyudin, Management information System (Sistem Informasi Manajemen), Edisi 2. Jakarta: Mitra Wacana Media, 2012.

[7] A.S. Munandar, Industrial and Organizational Psychology (Psikologi Industri dan Organisasi). Jakarta: Penerbit Universitas Indonesia, 2001.

[8] D.W. Organ, Organizational Citizenship Behavior: The Good Soldier Syndrome. Lexington, MA: Lexington Books, 2006.
[9] M. Ariyani and D. Zulkarnain, "Organizational Citizenship Behavior (OCB) pada Guru Ditinjau dari Faktor Demografi," Jurnal Penelitian dan Pengukuran Psikologi, vol. 6, no. (2), 2017.

[10] P.M. Podsakoff, S.B. MacKenzie, J.B. Paine, and D.G. Bachrach. "Organizational Citizenship Behavior: A Critical Review of the Theoretical and Empirical Literature and Suggestion for the Future Research,” Journal of Management, vol. 26, no. (3), pp. 513-563, 2000.

[11] C.A. Smith, D.W. Organ, and J.P. Near, "Organization Citizenship Behavior: Its Nature and Antecedents," Journal of Applied Psychology, vol. 68, no. (4), pp. 653-663, 1983.

[12] I. Fajriati, Comparative Analysis of Work Motivation and Work Discipline between Male and Female Employees as Role Models for Employees (Analisis Perbandingan Motivasi Kerja dan Disiplin Kerja antara Karyawan Laki-laki dan Perempuan sebagai Model Peran bagi Karyawan). [Skripsi]. Malang: Fakultas Ekonomi, Universitas Negeri Malang, 2011. [Online]. melalui URL: http://karyailmiah.um.ac.id/index.php/manajemen/article/view/20910 [Diakses 23 Pebruari 2020].

[13] J.W. Creswell and V.L.P. Clark, Mixed Methods Research. USA: Sage Publications, Inc., 2007, pp. 71-75. 